\title{
NILAI KEAGAMAAN CANDI KEMBAR BATU MUARA JAMBI SEBAGAI SUMBER PEMBELAJARAN SEJARAH
}

\author{
Oleh: Rati* \\ *Mahasiswa Program Studi Pendidikan Sejarah Universitas PGRI Palembang
}

\begin{abstract}
ABSTRAK
Masalah dalam penelitian ini adalah Bagaimanakah nilai keagamaan Kembar Batu Muaro Jambi dapat dijadikan sebagai sumber pembelajaran sejarah di SMA Aisyiyah 1 Palembang? Sedangkan Tujuan dari penelitian yaitu: mengetahui nilai keagamaan Candi Kembar Batu Muaro Jambi Kecamatan Marosebo Kabupaten Muara Jambi Metode yang digunakan dalam penelitian ini adalah deskriptif kualitatif dengan teknik pengumpulan data melalui observasi, wawancara dan dokumentasi. Sedangkan teknik analisis data yang digunakan dalam penelitian ini adalah teknik analisis data analisis intraktif melalui pengumpulan data, reduksi data, sajian data, dan vertifikasi atau penarikan kesimpulan.Berdasarkan hasil analisis data dan pembahasan yang telah dilakukan dalam penelitian ini maka dapat disimpulkan bahwa nilai keagamaan candi satu Muaro Jambi merupakan ilmu sejarah yang mempelajari keagamaan candi kembar batu Muaro Jambi yang dapat dijadikan sebagai sumber pembelajaran sejarah di SMA Aisyiyah 1 Palembang. Tata letak candi menunjukkan nilai keagamaan antara candi induk satu, candi induk dua, purwara dan juga stupa tata letak inilah yang menunjukkan ritual keagamaannya.
\end{abstract}

Kata Kunci: Nilai Keagamaan, Candi Satu Muaro Jambi, Sumber Pembelajaran Sejarah

\section{A. PENDAHULUAN}

Budaya adalah bentuk jamak dari kata "budi" dan "daya" yang berarti cinta, karsa dan rasa. Kata "budaya" sebenarnya berasar dari bahasa Sansekerta, budhaya, yaitu bentuk jamak kata budhi yang berarti budi atau akal. Dalam bahasa Inggris, kata budaya berasal dari kata culture. Dalam bahasa belanda diistilahkan dengan kata cultuur, dan dalam bahasa latin, berasal dari kata colera. Colera berarti men golah, dan mengerjakan, menyuburkan, me ngembangkan tanah (bertani) (Setiadi, 2006:27).

Temuan sejumlah besar arca batu dan logam di wilayah Palembang dan sekitarnya membawa kepada kesimpulan bahwa pusat Kerajaan Sriwijaya berdasarkan berita Cina pada abad ke-7 Masehi dapat ditafsirkan bahwa Sriwijaya semula berkembang agama Buddha Hinayana dan Mahayana.

Dalam era selanjutnya justru Buddha Mahayana yang berkembang secara pesat, dan menenggelamkan Buddha Hinayana. Sangat mungkin agama Buddha Mahayana disokong oleh dinasti raja-raja yang kuat berwibawa dan mampu mengembangkan kekuasannya di wilayah Jawa dan Sumatera, dinasti itu tidak lain Sailendrawangsa (Supartha, 2009:54-56).

Berdasarkan uraian diatas, maka penulis tertarik untuk melakukan penelitian dengan judul' 'Nilai Keagamaan Candi Satu Muaro Jambi Sebagai Sumber Pembelajaran Sejarah". Sumber belajar (learning resaurces) adalah semua sumber baik berupa data, orang dan wujud tentu yang dapat digunakan oleh beserta didik dalam belajar, baik secara terpisah maupun secara terkombinasi

sehingga mempemudah peserta didik dalam mencapai tujuan belajar atau mencapai kompetensi tertentu. Sumber belajar dapat berupa buku-buku rujukan referensi, atau literatur, baik untuk menyusun silabus maupun dalam proses kegiatan belajar mengajar (Iskandar, 2009:196).

\section{B. METODE PENELITIAN}

Metode yang yang digunakan oleh peneliti adalah metode penelitian deskriptif 
kualitatif. Berdasarkan rumusan masalah, penelitian mendeskripsikan secara rinci tentang Situs Candi Kembar Batu Muara Jambi sebagai sumber mata pelajaran sejarah di SMA Aisyiyah 1 Palembang. Untuk memahami hal tersebut, di lakukan penelitian mengenai nilai sejarah yang dimiliki Situs Candi Muara Jambi yang dapat dijadikan sumber pembelajaran di SMA Aisyiyah 1 Palembang.

\section{Sumber Data}

Sumber data penelitian ini:

a. Informan/Narasumber dalam penelitian ini adalah Ibu Ratna Wati selaku pengelola Situs Candi Kembar Batu Muara Jambi, guru sejarah di SMA Aisyiyah 1 Palembang Ibu Meri Yeni Ahca.

b. Arsip dan dokumen yang relevan yang berhubungan dengan penelitian serta silabus mata pelajaran sejarah kelas X SMA Aisyiyah 1 Palembang.

c. Observasi lapangan dilakukan di Situs Candi Kembar Batu Muara Jambi dan SMA Aisyiyah 1 Palembang.

\section{Teknik Pengumpulan Data}

1. Observasi Langsung

Dalam penelitian ini observasi dilakukan di Situs Candi Kembar Batu Muara Jambi dan dikelas X Sekolah Menengah Atas Aisyiyah 1 Palembang Tahun Ajaran 2016/2017.

\section{Wawancara Mendalam}

Dalam penelitian ini peneliti melakukan wawancara kepada pegawai Situs Candi Mura Jambi untuk mengetahui lebih dalam mengenai informasi nilai sejarah dan nilai agama peninggalan-peninggalan Situs Candi Kembar Batu Muara Jambi Ibu Ratna Wati.

\section{Dokumentasi}

Dalam pengumpulan data pada penelitian ini peneliti mengumpulkan dan menyelidiki data-data tertulis tentang peninggalan-peninggalan Candi Kembar Batu Muara Jambi yang termuat dalam laporan-laporan hasil penelitian Balai
Arkeologi Palembang peneliti juga mengumpulkan data dari dokumen pembelajaran sejarah Sekolah Menengah Atas Aisyiyah 1 Palembang.

\section{Teknik Analisis Data}

Analisis data yang digunakan dalam penelitian ini adalah analisis model intraktif. Dalam analisis data model intraktif terdiri dari tiga komponen yaitu; reduksi data, sajian data, dan penarikan kesimpulan.

\section{Vallidasi Data}

Setelah data berhasil didapatkan, dikumpulkan serta dicatat dalam penelitian maka tidaka kalah penting mengembangkan validitas data yang diperoleh. Sehingga proses pemaparan hasil penelitian, pembahasan dan penarikan kesimpulan menjadi pas.

Trianggulasi yang digunakan dalam penelitian ini ialah trianggulasi data. Melalui beberapa sumber data yang berbeda-beda untuk mengetahui kebenaran dari permasalahan. Dari sumber data yang berbeda-beda dan teknik pengumpulan data yang berbeda sehingga peneliti dapat memperoleh kebenarannya. Data diambil dari beberapa sumber seperti pengelola Situs Candi Muara Jambi, sedangkan teknik pengumpulan data yang digunakan ialah metode observasi, wawancara, dan dokumentasi untuk mengetahui nilai agama pada Situs Cndi Kembar Batu Muara Jambi.

\section{HASIL DAN PEMBAHASAN}

Nilai Sejarah Situs Candi Kembar Batu Muara Jambi

\section{Candi Kembar Batu Muara Jambi}

Kompleks candi Kembar batu terletak sekitar 250 meter di sebelah tenggara Candi Tinggi. Kompleks candi ini terdiri dari candi induk, perwara, pagar keliling dengan gapura, dan candi perwara disebelah timur terdapat tiga bangunan, satu perwara ditimur barat, dan dua perwara di sebelah utara. Berdasarkan keletakannya Kompleks Candi Kembar Batu berada lebih tinggi 2,5 sampai 3 meter dari daratan sekitarnya. Kemungkinan permukaan tanah lahan 
kompleks candi telah ditinggikan dengan cara menimbun tanah dari galian parit yang mengelilinginya. Temuan penting dari Komplek Candi Kembar Batu adalah sebuah gong terbuat dari perunggu dan terdapat inskripsi berhuruf Cina. Gong ini ditemukan dekat tangga naik candi induk dan sekarang disimpan sebagai koleksi Meseum Negeri Jambi. Selain itu di temukan pula pecahan arca dari batu dan perunggu, 12 lempengan emas, batu mulia, pecahan keramik Cina dan tembikar (Siddhyatra, 2012:51).

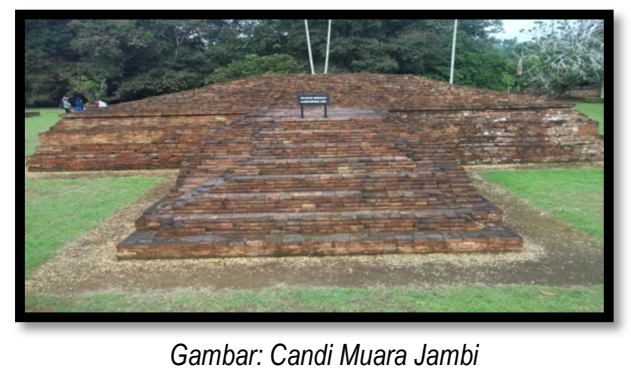

Pada halaman kelompok Candi Kembar Batu yang denahnya berbentuk bujur sangkar dengan ukuran $50 \times 64$ meter terdapat 7 buah bangunan bata. Gejala yang aneh dari kelompok candi ini adalah letak gapura pintu masuk halaman candi. Bangunan gapura ini terletak dekat dengan sudut timur laut tembok pagar keliling (Utomo, 2011:151152).

Menurut Mundarjito (2009:1) Situs

Muara Jambi merupakan tinggalan kebudayaan klasik masa Sriwijaya dan Melayu Kuno yang dipergunakan dalam masa yang cukup panjang sejak awal 7 hingga $15 \mathrm{M}$, sebagaimana di kutip dari sumber sejarah kekaisaran Cina dan Krajaan Majapahit yang berpusat di Jawa Timur. Kompleks percandia Buddish ini kemungkinan pernah di kunjungi pendeta Itsing pada tahun $671 \mathrm{M}$, yaitu ketika ia singgah di She-li-fo-she (Srivijaya) dan Molo-yeu untuk mendalami bahasa Sansekerta selama beberapa bulan sebelum berangkat ke Nalanda-India.
Menurut Soebadayo (1998:77) Muara Jambi bertanggal abad ke-11 hingga ke-13, satu-satunya situs bangunan batu bata masa Klasik di sumatera yang relatif sangat terpelihara, dapat dikaitkan dengan data kesejarahan Melayu yang telah ada pada awal abad ke-7, mempunyai pusat politik dan kebudayaan di sepanjang Sungai Batanghari, sekitar tahun 1080. Melayu menggantikan Sriwijaya sebagai kerajaan yang menguasai Sumatera. Situs Muara Jambi terdiri atas 12 bangunan yang masih berdiri, kira-kira 21 gundukan batu bata dan tanah tak tergali, seluruh bangunan merupakan tempat suci Agama Budha.

\section{Kehidupan Keagamaan di Candi Kembar Batu \\ Menurut Siddhyatra (2012:45-} 49) Situs Muara Jambi secara administratif terletak Didesa Muara Jambi, kecamatan Marosebo, Kabupaten Muara Jambi, Propinsi Jambi. Situs ini terletak di tepi sungai batanghari, berjarak kurang lebih 25 $\mathrm{km}$ di sebelah timur kota Jambi. Situs Muara Jambi sudah dikenal oleh Crook sejak tahun 1820 setelah mengunjungi peninggalan purbakala disini dan berpendapat bahwa Situs Muara Jambi dahulunya merupakan sebuah ibukota dari suatu kerajaan.

Dalam tulisannya Schnitger juga mengajukan hipotesis bahwa pada tahun 671 Itsing pernah tinggal di Muara Jambi selama dua bulan. Pada tahun 695 Kerajaaan Melayu di tepi sungai ini Menyerang Sriwijaya. Pada tahun 853 dan 857 kerajaan ini mengirim utusan ke Cina dengan nama Tchan-pei (Jambi) tahun 1024 Kerajaan ini dapat mengalahkan Rajendracola dan pada tahun 1079, 1082 dan 1088 mengirim utusan ke Cina.

Dengan adanya sejumlah temuan tersebut dapat diketahui bahwa di Situs Muara Jambi merupakan situs permukiman, yang berdasarkan hasil kajian Moendarjito dalam skla makro berpola linear mengikuti aliran Sungai Batanghari. Meskipun demikian, bagaimana hubungan antar 
bangunan yang ada disitus Muara Jambi belum diketahui. Begitupun dengan pola pemukiman dalam persinggihan sementara yang mudah berpindah-pindah. Bangunan candi yang telah ditemukan sampai saat ini berjumlah sebelas, yaitu Candi Koto Mahligai, Candi Kedaton, candi Gedong 1, Candi Gedong 2, Candi Duku, Candi Gumpung, Candi Kembar Batu, Candi Tinggi 1, Candi Tinggi II, Candi Astano dan Candi Teluk. Dari beberapa candi yang ada disitus Muara Jambi dapat diketahui bahwa hampir semua candi mempunyai denah bujur sangkar, hanya dua candi yang berdenah segi empat yaitu Candi Gumpung dan Candi Tinggi. Candi Astano berdenah segi 10 (Mundardjito, 1984:243).

\section{Kepercayaan Masyarakat di Candi Kembar Batu}

Menurut Darini (2016:45-46) Pada awalnya aliran agama Budha Hinayana berkembang pesat di Sriwijaya, namun aliran Hinayana terdesak oleh perkembangan ajaran Budha Mahayana. Beberapa arca ditemukan di situs Muara Jambi antara lain arca Prajnaparamita dan makara di perkirakan bahwa situs Muara Jambi pada masanya (antara abad ke-1213) merupakan pusat aktivitas agama Mahayana yang cukup ramai. Sisa-sisa bangunan yang merupakan bekas wihara atau dharmmasala yang mengidentifikasikan banyaknya kaum agamawan yang melakukan yang melakukan ritus pribadatan di pusat keagamaan tersebut. Jadi dapat diketahui bahwa kepercayaan masyarakat Candi Kembar Batu adalah aliran agama Budha Mahayana.

$$
\text { Menurut Kung }
$$

Buddhisme adalah sebuah ajaran yang agung dan sempurna, yang diajarkan langsung oleh Buddha kepada semua makhluk hidup di dalam sembilan alam kehidupan. Buddha berasal dari bahasa Sanskerta yang berarti kebijaksanaan dan pencerahan. Dalam filosofi, dikenal adanya subjek dan objek. Sedangkan dalam
Buddhisme Mahayana, tidak ada perbedaan antara subjek dan objek, mereka adalah satu kesatuan. Pengertian ini sangatlah dalam dan sulit untuk dipahami.

Menurut Darini (2016:45-46) Aliran agama Buddha Hinayana merupakan aliran agama yang pada awalnya berkembang pesat di Sriwijaya. Hal ini diketahui dari sumber-sumber Cina. Parapendeta Cina yang datang ke Sumatera dan Jawa justru mempelajari kitab-kitab Buddha Hinayana namun demikian dalam proses perkembangannya aliran Hinayana ini justru terdesak oleh perkembangan ajaran agama Buddha Mahayana, baik di Jawa maupun di Sumatera. Perkembangan aliran Buddha Mahayana di Sumatera di kuatkan dengan peninggalan-peninggalan material berupa monumen, arca, relief, maupun prasasti. Kemungkinan besar aliran Mahayana yang meluas karena adanya dukungan dari dinasti raja-raja yang kuat, yaitu Dinasti Syailendra. Di wilayah Jambi banyak ditemukan benda-benda kepurbakalaan dari bata. Oleh masyarakat setempat situs tersebut dinamakan candi Astano, Tinggi, Gumpung, Kembar Batu, Kedaton, dan lainlain. Namun arsitek candi-candi ini berbeda dengan candi yang terdapat di Jawa Tengah atau Jawa Timur.

Menurut Supartha (2009:39) Berdasarkan sumber-sumber cina dapat diketahui pada awalnya agama Budha yang pesat berkembang di Sriwijaya adalah Budha dari aliran Hinayana. Para pendeta Cina yang berkunjung Ke Sriwijaya dan Jawa, justru mempelajari kitab-kitab suci Budha Hinayana. Dalam perkembangan selanjutnya karena sesuatu sebab yang belum dapat di jelaskan, maka perkembangan agama Budha Hinayana baik di Sriwijaya ataupun di Jawa kemudian terdesak oleh perkembangan agama Budha Mahayana.

Menurut Erwin (1990:16-21) Lahir dan berkembangnya agama budha. Berlainan dengan agama Hindu yang lahir tanpa wahyu dari manapun, agama Buddha 
muncul melalui ilham yang datang kepada seorang ksatrya bernama Gautama. Ketika gama Hindu berkembang dengan pesat, ketamakan kaum Brahmana makin menjadi. Karena hanya mereka yang mampu membaca serta menyelenggarakan berbagai upacara keagamaan mereka mulai mengkomersialkan profesinya secara berlebihan. Upah yang diminta tidak sesuai dengan pekerjaan yang dilakukan, sehingga masyarakat mulai jenuh dengan tingkah laku mereka. Sebagai reaksi langsung, bermunculan berbagai aliran yang menentang agama Hindu di masyarakat.

Di dalam agama Budha ada dua aliranyaitu: Hinayana dan Mahayana. Aliran Hinayana adalah aliran yang terkenal dengan kendaraan kecil yaitu bahwa orang yang dapat masuk Nirwana hanya dengan kekuatan sendiri, tanpa bantuan siapapun. Karena itu tidak banyak orang yang bisa mencapai Nirwana. Aliran Mahayana adalah aliran yang disebut kendaraan besar. Setiap orang bisa masuk Nirwana dengan bantuan dewa-dewa. Padahal sejak semula Sidharta Gautama mengajarkan bagaimana mencapai kebahagiaan dalam hidup, dia tidak pernah mengajarkan dan menyebutkan nama tuhan dan dewa-dewa. Dengan adanya dewa-dewa atau BodhisatwaBodhisatwa didalam Budha maka perbedaan antara Budha dan hindu makin samar-samar. Seperti juga agama hindu, nasib agama Budha di India dinodai para ulamanya yang sudah lupa daratan karena terlalu banyak diberi hadiah dalam melakukan upacara keagamaan. Akhirnya makin sedikit penganutnya di India dan agama Budha lebih banyak dianut di negara-negara lain seperti Tibet misalnya yang akhirnya menjadi pusat agama Budha.

Menurut Soekmono (1973:17) Pada mulanya agama Budha itu sebenarnya bukan agama, dalam arti adanya Tuhan atau Dewa yang dipuja, melainkan sesuatu ajaran yang bertujuan membebaskan manusia dari lingkaran samsara (moksa). Dalam hal ini agama Budha tiada bedanya dengan ajaran-ajaran lainnya yang sudah kita kenal, seperti Wedanta, samkhya dan Yoga. Memang agama budha berpangkal kepada kupasan-kupasan Upanisad pula, hanyalah jalan yang di tempuh olehnya sebagai hasil pencariannya berlawanan dengan dengan jalan Wedanta dan lebih dekat kepada samkhya dan Yoga..

Menurut Utomo (2011:34-37) Ajaran Budha meluas pemeluknya terjadi pada abad ke-7-10 Masehi. Pada waktu itu sebuah kerajaan yang kuat dan berpengaruh di Asia Tenggara adalah Sriwijaya. Kerajaan ini selain dikenal sebagai kerajaan maritim, juga dikenal sebagai kerajaan yang adilnya cukup besar dalam perkembangan ajaran Budha. Biksu Budha dari berbagai bangsa datang ke Sriwijaya untuk mempelajari tata bahasa Sansekerta sebelum melanjutkan pelajarannya ke Nalanda di India. Bahkan Atisa, seorang biksu Budha dari Tibet menyempatkan diri untuk memperdalam ajaran Budha di Sriwijaya. Pengaruh Sriwijaya di Thailand Selatan cukup kuat. Hal ini tampak gaya seni arca yang ditemukan dari kawasan ini. Banyak arca Budha dan Bodhisattwa yang dikatakan berlanggam Sailendra, Sriwijaya, ataukadang-kadang disebut berlanggam Semenanjung.

Muara Jambi merupakan kompleks bangunan suci Budha Mahayana. Para penziarah datang untuk melakukan upacara. Diduga para peziarah itu datang dan bermalam dibagian luar tembok keliling bangunan suci. Ekskavasi arkeologi yang dilakukan di bagian luar tembok keliling banyak menemukan anglo berbentuk sepatu. Anglo jenis ini dibawa-bawa. Dihalaman luar bangunan Kedaton ditemukan sebuah belanga yang berukuran besar dengan garis tengah sekitar 1 meter, dan dibuat dari bahan perunggu. Belanga ini biasa dipakai untuk memasak dalam volume yang besar. Mungkin saja dipakai ketika d Muara Jambi sedang berlangsung upacara besar, seperti peringatan hari Trisuci 
Waisak. Kompleks Muara Jambi kini dimanfaatkan kembali oleh umat Budha dari daerah Jambi. Tidak tertutup kemungkinan umat Budha dari tempat lain di Sumatra maupun luar Sumatra.

Menurut Magetsari (1997:107) Proses penganutan agama Budha dan agama Hindu lebih dilihat dari segi perubahan kebudayaan, bahkan sebagai proses pembudayaan. Agama budha termasuk Tantrayana, di India hanya berkembang sampai akhir abad kedua belas ajaran tantrayana itu, sebelum punah dari India, telah dianut oleh Bangsa Tibetdan dipelihara sampai sekarang.

Sang Hyang Mahayana ajaran yang akan diturunkan dalam bagian ini dikatakan sebagai Sang Hyang Kemahayanaanyang disingkat SHK. Dapat dikatakan bahwa hubungan yang ada anatara Mahayana dengan Mantrayana dimulai dari pemupukan (sambhara) 'kebajikan' (punya) dan 'pengetahuan' (jnana) melalui plaksanaan ajaran Mahayana. 'pemupukan' ini, dalam tingkat phala, dicapai melalui jalan Mantrayana, untuk kemudian mengalami kesempurnaan. Menurut Riclefs (2013:4550) Sriwijaya sangat dipengaruhi agama Budha. Biksu Yijing dari Cina yang mengunjungi Sriwijaya pada abad ke-7 menulis dengan kagum tentang betapa ta,atnya kerajaan ini kepada agama. la juga menulis mengenai besarnya komunitas biksu internasional yang terlibat dalam penerjemahan kitab suci agama Budha kedalam berbagai bahasa. Seperti ditempat lain, tidak ada agama yang menikmati monopoli total. Meski agama Budha sepertinya lebih mendominasi, patungpatung Wisnu juga ditemukan di Sumatra dan Semenanjung Malaya.

Menurut Riclefs (2013:99) Akar Theravada sebagai ajaran Budha yang berbeda dengan Mahayana yang diperaktikan di Cina, Vietnam dan tempattempat lainnya dimulai pada abad-abad setelah wafatnya Sang Budha. Ketika itu, serangkaian dewan bertemu untuk membahas masalah doktrindan praktik yang selalu berujung pemecahan internal agama. Perdebatan awal banyak berkutat pada penafsiran berbeda terhadap Vinanya aturan terperinci untuk mengawal prilaku para biksu yang secara keseluruhan dikenal sebagai Sangha. Kurang lebih pada akhir abad ke-3 SM sekte Mahayana dan Theravada mulai menempuh jalannya masing-masing. Perpecahan Mahayana denga Theravada pada awalnya hanya terkait disiplin-disiplin spesifik yang harus diikuti para biksu.

Menurut Ardika (2002:56) Agama Hindu dan agama Budha tidak diperkenalkan kepada bangsa Indonesia melalui paksaan atau penjajahan, juga tidak diperkenalkan oleh saudagar-saudagar seperti diduga sebelumnya. Peristiwaperistiwa budaya dan agama, pengenalan bahasa Sansekerta untuk menulis dan penerimaan mitologi Budha dan Hindu bukanlah para saudagar. Yang lebih besar kemungkinannya ialah bahwa pangeranpangeran yang berkuasa di kerajaankerajaan kecil di Indonesia dipengaruhi oleh para pendeta dan brahmana dari India. Pendeta-pendeta ini bertanggung jawab atas pengenalan suatu agama yang memungkinkan raja mengidentifikasikan dirinya dengan dewa atau bodisatwa sehingga memperkuat kekuasaannya. Unsur-unsur budaya yang lebih abstrak juga berperan, seperti konsep cekravartin (penguasa alam semesta), warna (kelas sosial), adanya kekuatan gaib tertinggi, rasa dalam estetika, dan semua wujud artistik dan konsep-konsep tersebut.

Menurut Ardika (2002:56) Pada permulaan abad ke-11 kerajaan Sriwijaya di Sumatera menguasai selat malaka dan mempunyai hubungan baik dengan Cina dan kerajaan Chola di India selatan. Arsip Cina menyimpan laporan tentang pemusuhan antara sumatera dan Jawa. Pada tahun 1025 bangsa Chola menyerang dan menangkap raja Sriwijaya setelah kekuatan Sriwijaya patah, pelabuhan- 
pelabuhan dagang baru mulai muncul di Jawadan Sumatera, dipacu oleh kedatangan pendatang pertama dari Cina. Letak kota Cina 'benteng Cina' di Sumatera timur laut yang muncul menjelang akhir abad ke-11, merupakan contoh paling tua sebuah kota di Indonesia dengan aneka ragam bidang pekerjaan, bukti perdagangan luar negeri yang giat, penduduk aneka bangsa dan suku bangsa, dan suatu perekonomian moneter.

Jambi banyak mengirim banyak duta ke Cina-petunjuk atas ambisikerajaan inidan mendapat dukungan raja Cola untuk sebuah Candi di India selatan yang dibangun beberapa dasawarsa sebelumnya ketika Sriwijaya-Palembang masih menguasi daerah itu. Pengembangan kerajaan dengan perekonomian yang cemerlang dipinggir lembah Batang Hari, raja melayu Jambi memberi contoh atas kesiapan penduduk maritim menyesuaikan diri dengan perubahan perekonomian.

\section{Simbol Keagamaan dalam Agama Budha}

Simbol keagamaan dalam agama Budha dapat dibedakan atas beberapa bagian menurut jenis dan bentuknya yaitu seperti stupa dan candi, binatang singa, tumbuhan seperti teratai.

Menurut Soedewo (2012:5) Singa sering disebut sebagai raja hutan, walaupun pada kenyatannya binatang ini tidak selalu hidup di dalam hutan. Singa dianggap merupakan raja dari kerajaan binatang. Hal tersebut kemungkinan karena singa tidak mempunyai musuh alami dalam kehidupan mereka. Singa mudah dikenali dari tubuhnya yang bewarna keemasan. Adapun hal yang membedakan antara singa jantan dan betina adalah pada singa jantan terdapat surai di sekeliling kepala serta punggungnya. Mereka selalu hidup dalam kelompok dan mendapatkan makanan melalui aktivitas berburu yang dilakukan oleh singa betina. Adapun pekerjaan singa jantan adalah sebagai pelindung, pengambil kebijakan, dan kebanggaan kelompok. Oleh karena itu singa sering dijadikan sebagai simbol berbagai kebudayaan. Dalam kebudayaan India, singa kerap muncul bersama dengan sapi brahmana (zebu), gajah, dan kuda sebagai empat binatang yang mendekorasi pilar-pilar dalam kuil-kuil Budha. Keempat binatang tersebut merupakan perwujudan dari keempat lingkaran samsara.

Buddhisme awal mengadopsi singa sebagai simbol dari Sakyamuni Budha, yang dikenal sebagai singa dari keluarga Sakya. Sebagai simbol dari kebanggaannya digambarkan singgasananya ditopang oleh delapan singa. Delapan singa tersebut mengacu pada delapan anak Budha. Simhanada atau yang sering disebut sebagai auman singa merupakan salah satu perwujudan Avalukitesvara. Singa juga menjadi kendaraan beberapa dewa dalam vajrayana seperti vakhravana, Manjushri, Manjushri, Ganapati, dan Tashi Tseringma dan menjadi vahana Ratnasambhwa dan Vairocana. Dalam Budhisme, singa merupakan simbol dari Bodhisattva yang merupakan anak-anak Budha. Atau sering disebut singa Budha

Menurut Suhartono (2009:36) Motif hias teratai sangat populer penggunannya pada masa Hindu-Budha. Di dalam kebudayaan Hindu Budha motif hias teratai selalu dihubungkan dengan filsafat ketuhanan dan sering digunakan simbol yang mempunyai arti kesucian, lambang kelahiran, maupun kehidupan (Zimmer, 1962:22). Bunga teratai merupakan lambang kehidupan semua dewa atau juga merupakan merupakan lambang dari alam semesta sebagai tanda keagungan alam ciptaan Brahmana. Brahmana juga sering disebut Kamalasana, sejak ia duduk diatas bunga teratai yang tumbuh dari pusar Wisnu. Didalam Rg weda disebut prajapati. Selain itu juga disebut Svayambhu dan Hiranyagarbha, yaitu benih kehidupan, penciptaan dan kemakmuran.

Menurut Erwin (1990:18) Pohon merupakan simbol umum yang lazim 
digunakan untuk menggambarkan alam, selama berabad-abad, pepohonan telah menyediakan naungan dan perlindungan bagi manusia maupun binatang. Pohon Bodhi adalah pohon tempat naungan bertapa mencari kebahagiaan hidup. Ilham ia dapat di bawah sebuah pohon ara di Bodh Raya, yang sampai sekarang disebut pohon Bodhi. Saat ini pohon Bodhi dihormati sebagai pencerminan keagungan dan kebijaksanaan Sang Budha. Pohon Bodhi juga dilambangkan sebagai pohon kehidupan. Menghormat pada pohon Bodhi merupakan salah satu cara untuk menunjukkan rasa penghormatan dan syukur bagi umat Budha.

Menurut Soekmono (1973:80) Sebagaimana diketahui, kebudayaan itu meliputi seluruh hasil usaha manusia, baik hasil itu berupa benda ataupun hanya berupa buah pikiran dan alam penghidupan saja. Sejarah kebudayaan ini semakin membatasi diri. Barang-barang yang kita anggap biasa, yang selalu harus ada pada manusia. Dengan demikian maka mulai jaman purba sudah sejarah kebudayaan itu semakin menjadi sejarah kesenian. Jadi bukti simbol keagamaan Budha yaitu adanya sebuah petinawasanga penyimpanan peripih dari Candi Jolotundo, yang lapiknya teratai merah.

Menurut Darini (2016:59-60) Candi merupakan istilah yang digunakan untuk menyebut sebuah bangunan peninggalan di Indonesia yang di pengaruhi oleh arsitektur Hindu-Buddha. Istilah candi dikaitkan dengan Candika yaitu salah satu nama Dewi Durga atau Dewi Kematian, sehingga candi sering dikaitkan dengan kematian, makam atau sebagai tempat memuliakan raja yang meninggal. Terkait dengan fungsinya seagai pemakaman, sebenarnya yang di simpan hanyalah pripih, yaitu sebuah wadah yang berisi antara lain zat-zat ragawi dari simati seperti potongan rambut, kuku dan lainnya. Pengertian candi sebagai tempat pemakaman hanya berlaku pada penganut agama hindu. Dalam agama Buddha, candi merupakan bangunan peribadatan.

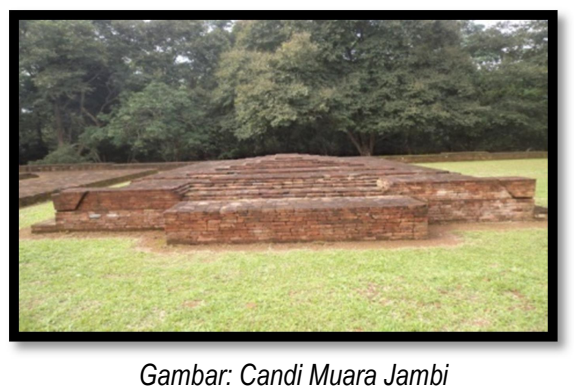

Menurut Nazir (1981:31) Stupa adalah simbol dari agama Budha. Stupa adalah sebuah benda atau bangunan suci pada agama Budha. Bentuknya merupakan sebuah bangunan kubah, berdiri diatas sebuah alas (= lapik) dan sebuah tiang puncak diatasnya. Tentang asal mula bentuk setupa itu, ada yang mewiriwayatkan sebagai berikut: tersebutlah dua orang pegikut pertama agama Budha yang diberi tanda mata oleh sang Budha, berupa potongan kuku dan rambut serta disuruh meyimpannya dalam stupa. Ketika ditanyakan apakah stupa itu, maka sang Budha membuka pakaiannya, lalu melipatnya menjadi empat persegi dan diletakkannya diatas tanah. Sebuah mangkok dalam posisi tertelungkup ditaruhkannya diatas lipatan pakaian itu. Kemudian tongkatnya ditegakkannya pula diatas mangkok tersebut. Itulah bentuk yang harus diberikan kepada benda yang disebut stupa.

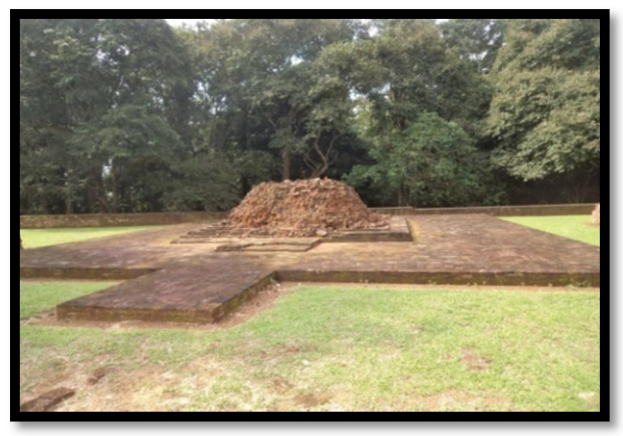

Gambar: Candi Muara Jambi 
Pada candi Kembar Batu terdapat Candi Induk satu dan candi induk dua, terdapat tiga Purwara, satu Stupa, dan satu Propan. Terdapat stupa inilah yang menjdi bukti bahwa penganut agama pada Candi Kembar Batu ini adalah agama Budha.

\section{Sinkretisme Hindu-Budha Pada Candi Kembar Batu}

Menurut Endraswara (2003:59-61) Kelonggaran budaya menerima keyakinan lain, menjadi Hindu Jawa ataupun Islam Jawa, sebenarnya tidak semata-mata sinkretisme murni. Sinkretisme adalah memadukan, mencampur, dan menyelaraskan dua keyakinan atau lebih. Sinkretifisme dalam penggabungannya keyakinan yang paling benar. Sinkretisme tak lepas dari kenisbian, sinkretisme bersifat divergen, longgar, adaptif, dan akomodatif. Sinkretisme merupakan "penyatuan" dua keyakinan atau lebih. "Penyatuan tidak harus menunggal, melainkan hanya pemaduan beberapa unsur saja. Demikian, sinkretisme paham religius yang mengarah pada ketuhanan.

Menurut Paeni (2009:17) Zaman Hindu Budha memperlihatkan lonjakan data berkenaan dengan seni pertunjukan. Hal ini lebih didukung oleh terdapatnya sumbersumber tertulis. Akulturasi dengan kebudayaan India, yang membawa agama Hindu dan Budha sebagai penanda utamanya, memperlihatkan juga pengaruh besar dibidang seni, termasuk seni pertunjukan. Relief-relief candi dengan jelas memperlihatkan adegan-adegan dimana orang menari dan bermain musik, maupun jenis pekerjaan yang berkaitan dengan seni. Di sana sini penggalan-penggalan karya serta memberikan pula deskripsi mengenai suatu pertunjukan, jenis instrumen musik. Bahkan, kadang-kadang tersirat pula kaidah estetik yang dijadikan acuan dalam pembuatan dan penikmatan karya seni.

Menurut Paeni (2009:159) Perjumpaan dengan budaya India dan Cina tak dapat bangsa ini dipungkiri, telah berpengaruh besar dalam budaya membangun di Indonesia. Budaya India dengan Hinduisme dan Budhisme telah memengaruhi kehidupan sehari-hari di beberapa daerah. Cara membangun bangunan ibadah seperti candi dan pura, meletakkan dasar-dasar arsitektur bangunan ibadah dan bertebaran di berbagai pelosok Indonesia. Budaya Cina juga menurunkan pengetahuan pertukangan, makanan dan seni tata letak yang populer kita kenal sebagai fengshui. Pertukangan kayu yang dibawa para pendatang orang Cina dan keturunannya memberi warna tersendiri. India dalam hal religi masyarakat awal Indonesia khususnya dan austronesia umumnya mengenal budaya punden berundak yang sering dihubungkan dengan kepercayaan animisme dan dinamisme atau pemujaan terhadap leluhur, bukan terhadap dewadewa seperti halnya dalam Hinduisme atau Buddisme.

Menurut Widharta (2014:21) Zaman Budha juga melahirkan kebudayaan seni rupa yang lahir dalam lingkungan kerajaan. Asia Tenggara dan selatan memiliki peninggalan seni Budha yang sangat beragam dengan ciri khasnya masingmasing. Tak kalah dengan yang lain, Indonesia juga mengalami perkembangan seni Budha yang monumental pengaruh yang kuat datang dari India.

Menurut Utomo (2011: 145-146) Prajnaparamita arca digambarkan duduk dengan kedua kaki dipahat mendatar, saling bertumpu (duduk bersila) dan kedua telapakdiarahkan keatas tangannya yang berjumlah dua dalam sikap witarkamudra. Rambutnya ditata menyerupai bentuk mahkota dan ikal-ikal rambut terlihat menjurai dibagian tengkuk dan diatas kedua bahu. Pakaian yang dipakai berupa kain yang tipis, berhias motif "ceplok" (bahasa jawa) dan panjang hingga pergelangan kaki. Bagian tepi sebelah bawah dari kain tersebut tampak digambarkan berlepit-lepit 
dan menutupi tempat duduk arca. Sebagai pegikat kain dipakai sampur bermotif lingkaran-lingkaran bulat, dan tampak simpul berbentuk pita pada bagian belakang badan (agak dibawah punggung). Ujungujung sampur menjurai dibagian depan dan menyentuh asana. Tali kastanya berupa untaian manik-manik. Jenis perhiasannya berupa kalung berjumlah dua untai, sepasang gelang lengan berhias bungan, sepasang gelang tangan berhias bunga, sebuah ikat dada, dan sepasang gelang kaki. Di sisi kiri arca terlihat setangkai padma.

Suleiman (1983: 202) dan Nik Hassan Shuhaimi (1984: 352) berpendapat bahwa penggambaran arca Prajnaparamita dari Muara Jambi mirip dengan arca Prajnaparamita dari Sinhasari yang memiliki priode, yaitu dari abad ke-13 Masehi. Jika dilihat dari perhiasan dan pakaian yang digambarkan cukupraya dan juga munculnya setangkai padma di sisi badan arca mencirikan bahwa arca Prajnaparamita dari Muara Jambi dapat dimasukkan dalam kelompok arca-arca yang bergaya seni Jawa Timur, yaitu dari masa Sinhasari. Dugaan bahwa arca Prajnaparamita dari Muara Jambi berasal dari abad ke-13 Masehi dapat didasarkan pada ciri-ciri tersebut.

Menurut Nazir (1980:27-28) Arca Dewi ditemukan penyelamatan dan pemugaran disamping candi Gumpung. Keadaannya sudah tidak lagi berkepala dan sebagian anggota tangangannya telah pata dan rusak. Tapi patahan pangkal lengannya masih dapat ditemukan walaupun sikunya sudah tidak ada lagi, hancur. Petugas proyek pemugaran candi di Muara Jambi menyebutnya dengan nama: Arca-Dewi. Penamaan demikian hanyalah didasarkan pada kecantikan arca itu, kehalusan ukirannya. Dan kesederhanaan perhiasannya tapi teratur rapi dan harmonis. Arca dewi itu dibentuk oleh senimannya dalam posisi duduk bersila diatas lapiknya yang berhiaskan kembang lotus. Wlaupun sebagian jari tangannya telah rusak, namun masih dapat diketahui mudranya, yang disebut dharmacakramudra. Jari kaki dan jari tangannya dihiasi pula dengan pelbagai cincin. Sebagian dari untaian rambutnya masih dapat diperhatikan pada bagian tubuhnya; tampak merupakan gambaran rambut keriting teratur. Lipatan pakaiannya mungkin merupakan hiasan kain batik dipahatkan denga teratur sekali seakanakan terpusat pada bagian belakang pinggangnya yang dibentuk merupakan sebuah bunga sedang mekar. Sang pemahatnya telah bekerja dengan baik sekali, sehingga area itu tampak sempurna menggambarkan seorang wanita cantik. Dapat kiranya dibayangkan betapa indahnya Arca-Dewi itu bila lengkap dengan leher dan kepalanya.

Tinggi arca itu termasuk batulapiknya, lebih kurang $90 \mathrm{~cm}$, sedangkan tinggi batu lapiknya saja lebih kurang $25 \mathrm{~cm}$. Jadi tinggi arca itu saja lebih kurang sma dengan tinggi seorang yang sedang duduk bersila. Kebanyakan para pengagum seni arca yang telah memperhatikan arca dewi di Muara Jambi itu, mensejajarkannya dengan arca Prajnaparamita yang pernah dinyatakan sebagai arca terindah di Indonesia. Arca Prajnaparamita melambangkan puteri Ken Dedes, permaisuri tercantik dari kerajaan Singosari.

Arca Gajah ditemukan 3 buah arca gajah di lokasi pemugaran candi Muara Jambi. Ditemukan terdapat disamping reruntuhan candi di Koto Mahligai. Mukanya arca itu telah rusak, sehingga agak sulit ditentukan hewannya. Penduduk setempat menyebutnya sebagai batu-babi. Berdasrkan ciri-ciri yang masih kelihatan (sebagian dari kakinya masih terbenam didalam tanah), diperkirakan bahwa arca tersebut merupakan arca gajah. Hewan lain yang berada di pundak slah satu arca itu sebagai pengendara layaknya, merupakan arca singa. Perpaduan yang demikian biasa terdapat dalam seni arca, di India. 
Umpak: batu sendi yang ditemukan pada candi Kembar Batu Muara Jambi. Umpak adalah lobang penyangga dari stupa, yang terdiri dari 12 lobang, umpak ini hanya tersisa dari reruntuhannya saja. Umpak ini diperkirakan sebagai lobang penyangga dari atap stupa.

\section{Pembahasan}

Nilai Keagamaan Candi Kembar Batu Muara Jambi Sebagai Sumber Pembelajaran Sejarah di SMA Aisyiyah I Palembang

Menurut Tumanggor (2015:142) nilai agama ketika manusia menilai satu rahasia yang menakjubkan dan kebesaran yang menggetarkan di mana di dalamnya ada konsep kekudusan dan ketakriman kepada yang maha gaib, maka manusia mengenal nilai agama.

Dari uraian diatas dapat disimpulkan bahwa nilai agama adalah kepercayaan manusia pada sesuatu yang gaib yang dapat dipercayanya seperti halnya ia mempercayai agamanya.

Dalam mata pelajara sejarah Kelas $X$ SMA Aisyiyah I Palembang bahwa nilai keagamaan Candi Kmbar Batu Muara Jambi pada kompetensi dasar 3.6 Menganalisis karakteristik kehidupan masyarakat kehidupan masyarakat, pemerintahan dan kebudayaan pada masa kerajaan-kerajaan Hindu Budha di Indonesia dan menunjukkan contoh bukti-bukti yang masih berlaku pada kehidupan masyarakat Indonesia masa kini. Candi Kembar Batu muara Jambi Merupakan hasil dari peninggalanpeninggalan masyarakat Hindu Budha, hal ini di buktikan dengan bangunan-bangunan pada candi.

Dalam memperoleh data peneliti melakukan penelitian langsung yakni wawancara kepada guru IPS Sejarah kelas $X$ yaitu lbu Meriyeni Ahca, S.Pd. berdasarkan wawancara dengan Ibu Meriyeni Ahca, S.Pd (Pada Tanggal 6 Mei 2017). Menurut beliau bahwa penggunaan sumber pembelajaran sejarah IPS Sejarah
SMA Aisyiyah I Palembang Khususnya Nilai keagamaan Candi Kembar Batu Muara Jambi belum pernah dilakukan, tetapi dalam pelajaran Hindu Budha sudah di singgung mengenai perbedaan candi Hindu Budha kalau secara langsung mengenai pembelajaran Candi Kembar Batu Muara Jambi belum dilakukan. Hal ini karena terbatasnya sumber-sumber bacaan yang membahas candi Kembar Batu Muara Jambi, Kemudian siswa sulit untuk mendapatkan info tentang sejarah Candi Kembar Batu Muara Jambi karena candi Kembar Batu Muara Jambi belum masuk dalam buku sumber Sejarah yang dijadikan pedoman dalam pembelajaran Sejarah.

Berdasrkan hasil wawancara dengan Ibu Meriyeni Ahca, S.Pd guru mata pelajaran sejarah pada tanggal 6 Mei 2017. Dengan adanya pengenalan materi nilai keagamaan Candi Kembar Batu Muara Jambi sebagai sumber pembelajaran sejarah dapat menambahkan dan mempermudah tenaga pengajar untuk memperkenalkan peninggalan-peninggalan agama Hindu Budha Khususnya Nilai Keagamaan Candi Kembar Batu Muara Jambi yang mengenai sejarah agama Hindu Budha dan tata letak candi kepada siswasiswi sehingga peserta didik dapat diketahui tentang Nilai keagamaan Candi Kembar Batu Mura Jambi.

\section{Sumber Pembelajaran Sejarah Tentang Nilai Keagamaan Candi Kembar Batu Muara Jambi di SMA Aisyiyah 1 Palembang \\ Sumber belajar (learning resaurces)} adalah semua sumber baik berupa data, orang dan wujud tentu yang dapat digunakan oleh beserta didik dalam belajar, baik secara terpisah maupun secara terkombinasisehingga mempermudah peserta didik dalam mencapai tujuan belajar atau mencapai kompetensi tertentu. Sumber belajar dapat berupa buku-buku rujukan referensi, atau literatur, baik untuk menyusun silabus maupun dalam proses 
kegiatan belajar mengajar. (Iskandar, 2009:196)

$\begin{array}{rrr}\text { Sumber } & \text { Pembelajaran di } \begin{array}{r}\text { SMA } \\ \text { Aisyiyah } 1\end{array} \text { Palembang banyak }\end{array}$ menggunakan berbagai referensi yaitu dari buku-buku sejarah, serta survei kelapangan ke museum-museumdan situs-situs sejarah yang ada di palembang sesuai dengan meteri pelajaran di kelas.

\section{KESIMPULAN}

Berdasarkan uraian bab-bab terdahulu, maka penulis mengambil kesimpulan sebagai berikut:

Muara Jambi bertanggal abad ke-11 hingga ke-13, satu-satunya situs bangunan batu bata masa Klasik di sumatera yang relatif sangat terpelihara, dapat dikaitkan dengan data kesejarahan Melayu yang telah ada pada awal abad ke-7, mempunyai pusat politik dan kebudayaan di sepanjang Sungai Batanghari, sekitar tahun 1080. Melayu menggantikan Sriwijaya sebagai kerajaan yang menguasai Sumatera. Situs Muara Jambi terdiri atas 12 bangunan yang masih berdiri, kira-kira 21 gundukan batu bata dan tanah tak tergali, seluruh bangunan merupakan tempat suci Agama Budha.

Candi Kembar Batu Muaro Jambi, Kehidupan keagamaan Candi kembar batu pada awal penganutnya yaitu agama Hindu dengan dibuktikan adanya temuan abu biku dan saat ini penganutnya yaitu agama Budha dengan dibuktikan adanya Stupa dan juga setiap tahunnya para penganut agama Budha selalu datang baik dari masyarakat Jambi maupun orang luar Kota Jambi datang ke Candi Kembar Batu untuk sembahyang. Dan ritual sembahyangnya itu dengan cara mengelilingi kedua Candi Kembar Batu. Candi Kembar Batu merupakan salah satu warisan budaya agama Budha yang bernilai sangat tinggi. Dimana pada bagian-bagian yang terdapat pada bangunan Candi tersebut dapat menunjukkan bahwa zaman dulu Candi Muaro Jambi ini pernah dijadikan sebagai salah satu pusat tempat peribadatan agama
Budha Tantri Mahayana di Indonesia. Bahkan hal ini juga diperkuat dengan adanya beberapa hasil temuan benda sejarah yang terdapat pada candi Kembar Batu seperti halnya reruntuhan Stupa. Selain itu ditambah dipertegas dengan datangnya sekelompok para Rohaniawan Budha yang berasal dari luar Negeri dan para biksu asal Tiongkok yang juga datang ke Candi Muaro Jambi Candi Kembar Batu Khususnya.

\section{DAFTAR PUSTAKA}

Ardika, dkk. 2002. Sejarah Awal. Jakarta: PT Widyadara

Arikunto, Suharsismi. 2010. Prosedur Penelitian Suatu Pendekatan Praktik. Yogyakarta: PT Rineka Cipta.

Aris, Munandar dan Agoes, dkk. 2002. Arsitektur. Jakarta: PT Widyadara.

Arsyad, Azhar. 2014. ModelModel Pengajaran dan Pembelajara. Yogyakarta: Pustaka Pelajar.

Bonawati, Eva. 2012. Geografi Indonesia. Yogyakarta: Ombak.

Darini, Ririn. 2016. Sejarah Kebudayaan Indonesia Masa Hindu Budha. Yogyakarta: Ombak.

Departemen Pendidikan Nasional. 1999. Keramik Asing Dalam Tinjauan Bentuk Fungsi dan Ragam Hias. Palembang. Proyek Pembinaan Permuseuman.

Direktorat Jenderal Kebudayaan. Aneka Ragam Khasanah Budaya Nusantara III. Jakarta: Dinas Pendidikan dan Kebudayaan.

Endraswara, Suwardi. 2003. Mistik Kejawen. Sumatera Selatan: Narasi.

Enslikpedia Nasional Indonesia, Jilid 4. Jakarta: TP. Delta Pamungkas.

Ensiklopedi Naisonal Indonesia Jilid 4. 2004. Jakarta: PT. Delta Pamungkas.

Erwin, Tuti Nuriah. 1990. Asia Selatan Dalam Sejarah. Jakarta: Fakultas Ekonomi Universitas Indonesia. 
Hugiono, dan P.K Poerwantana.1992. Pengantar IImu Sejarah. Jakarta: Rineka Cipta.

Iriani, dkk. 2001. Lintas Keramik. Bandung: Bagian Proyek Pembinaan Permuseuman Jawa Barat.

Iskandar. 2009. Psikologi Pendidikan. Jakarta: Gaung Persada.

Kahar, Thabran, dkk. 1979. Cerita Rakyat Daerah Jambi. Jakarta: Balai Pustaka.

Madjid dan Wahyudhi. 2014..IImu Sejarah Sebuah Pengantar. Jakarta: Prenada Media Grub.

Majid, dkk. 2004. IImu Sejarah Sebuah Pengantar. Jakarta: Prenada Media Group

Magetsari, Noerhadi. 1997. Candi Borobudur Rekonstruksi Agama dan Filsafatnya. Depok: Fakultas Sastra Indonesia.

Mundarjito, dkk. 2009. Muaro Jambi Dulu, Sekarang dan Esok. Palembang. Balai Arkeologi Palembang.

Nata. 2012. Metodelogi Studi Islam. Jakarta: Rajawali Pers.

Natzir. 1981. Arkeologi Klasik Daerah Jambi. Jambi:Museum Negeri Provinsi Jambi.

Paeni Mukhlis. 2009. Sejarah Kebudayaan Indonesia. Jakarta: PT Rajagrafindo Persada.

Prastowo, Andi. 2010. Menguasai TeknikTeknik koleksi data penelitian kualitatif (bimbingan dan penelitgian lengkap serba Guna). Yogyakarta: Diva Press.

Poesponegoro Dkk. 2010. Sejarah Nasional Indonesia. Jakarta: Balai Pustaka.

Rasyidi Bandri Dkk,1994.Pegangan Pendidikan Agama Islam.Bandung:Cv Armico.

Riclefs dkk. Sejarah Asia Tenggara Dari Masa Prasejarah Sampai Kontemporer. Komunitas Bambu

Rusman. 2011. Model-model pembelajaran. Jakarta: PT Raja Grafindo Persada
Setiaadi dkk. 2006 . IImu sosial budaya dasar. Jakarta: Kencana

Soedewo dkk. 2012. Fauna Dalam Arkeologi. Medan: Balai Arkeologi Medan

Soekmono. 1973. Pengantar Sejarah Kebudayaan Indonesia 2. Yogyakarta: Kanisius

Sugiono. 2013. Metode Penelitian Kuantitatif, Kualitatif dan Kombinasi Mixed Methods. Bandung: Alfabeta

Suhartono dkk. 2009. Konservasi Benda Cagar Budaya Borobudur. Balai Konservasi Peninggalan Borobudur

Sitangga, Cormenttyana, dkk. Kamus Pelajar Sekolah Lanjutan Tingkat Atas. Jakarta: Dapartemen Pendidikan Nasional

Sumardjo, Jakob. 2013. Arkeologi Budaya Indonesia. Yogyakarta: Palam.

Sukandarrumidi. 2012. Metodologi Penelitian Petunjuk Praktis Pemula. Yogyakarta: Gadja Mada University Press.

Supartha, I Made, dkk. 2009. Sejarah Kebudayaan Indonesia Religi dan Filsafah. Jakarta: Rajawali Pers.

Sanjaya, Wina. 2014. Strategi Pembelajaran Berorientasi Standar Proses Pembel ajara. Jakarta: Kencana Prenadamedia Group.

Siddhayatra. 2012. Jurnal Arkeologi. Palembang. Balai Arkeologi

Sutopo. 2006. Metodologi Penenlitian Kualitatif dasar teori dan terapannya dalam penelitian. Surakarta: Universitas Sebelas Maret.

Tamburaka, Rustam E. 1999. Pengantar IImu Sejarah, Teori Filsafat Sejarah, Sejarah Filsafat dan Iptek. Jakarta: PT Rineka Cipta

Utomo, Bambang Budi. 2001. Kebudayaan Zaman Klasik Indonesia Di 
Batanghari. Jambi:

Dinas

Kebudayaan dan Pariwisata

Wirjomartono, Bagoes, dkk. 2009. Sejarah

Kebudayaan Indonesia Arsitektur. Jakarta: Rajawali Pers

Widharta, Elyandra. 2014. Seni Rupa Asia. Yogyakarta. PT. Taka Publisher 